\title{
Two Moral Questions In Stem Cell Research Programme
}

\author{
Francis, Diana-Abasi Ibanga \\ Department of Philosophy, University of Calabar, Cross River State, Nigeria
}

\begin{abstract}
This study aimed to examine two important moral questions that are held against stem cell research by some scholars. These issues include: first, questions of right to life, and second, question of human dignity. This paper considered the arguments of the anti and pro hES cell research as well as the arguments of the gradualists. From the analyses, it was found that moral arguments held against hES cell research are weak, fallacious and, in some cases, shallow.
\end{abstract}

KEYWORDS: hES Cell, blastocyst, Stem cell, embryo, human dignity, right to life, Personhood

\section{INTRODUCTION}

In this paper, I shall examine the moral questions that have been brought to bear on stem cell research, with special emphasis on human embryonic stem (hES) cell research. At one end of the spectrum, it is argued that blastocyst have no moral status because it is not a human person, hence research with it should proceed without restriction. At the other end, it has been suggested that all clinical use of the blastocyst should stop since it requires the destruction of human embryos which is essentially the killing of human beings. Intermediate position has argued for the regulated use of hES cells under certain conditions. A consensus has not been reached amongst all the parties involved in the debate.

If indeed the blastocysts are human persons, the question arises whether the use of the blastocyst in research has not infringed upon their right to life and dignity as humans. On the other hand, if the blastocysts are not persons at all, does their worth count more than any other tissue in the body - such as the kidney? The objective of this paper, therefore, is to analyze and examine the ethical issues involve in stem cell research, especially the arguments that have been advanced to oppose hES cell research. Key themes involved include human dignity and right to life.

\section{THE QUESTION OF HUMAN DIGNITY}

One of the arguments marshalled against hES cell research is that it violates human dignity. Kristina Hug (2005) observes that some scholars have argued that hES cell research is incompatible with the notion of human dignity and the purpose of human life. The argument here is that using the blastocyst in research is not only akin to an assault on human individuality but on the very essence of human dignity. In fact, those who oppose hES cell research argue that the research involves many interventions and deliberate manipulation of the blastocyst.

This belief that the blastocyst has personal dignity that should be protected is based on a more fundamental argument that blastocysts are human persons with full moral status. And since, for them, the blastocyst is a human person with full moral status; it now argues that as human persons, they should not be used as means to an end. Their argument is based on Kantian notion of human dignity. According to Kant (1949), using human beings as means to achieve an end puts humans a par with mere objects - thereby undermining their personal dignity. The opponents of hES cell research argue that the blastocyst is a human person with intrinsic worth, therefore using it in research is tantamount to using it as means to an end (Austriaco, 2008). Moreover, Teo and Calbreath (2006) argue that "the embryo is a human person of intrinsic worth based solely on Almighty God's absolute valuation of the being." Their view is founded on an earlier position that the embryo carries with it the "image of God." Teo \& Calbreath view is corroborated by Austriaco (2008) that "human dignity is grounded in the truth that the human being is made in the image and likeness of God" (p.9). Now the question arises whether the blastocyt is a human person of whom its rights and dignity should be protected? This question has been answered in paper I published recently regarding the personhood status of the blastocyst (see Francis, 2016). On the other hand, those who encourage hES cells research argue that the blastocyst does not worth an iota of dignity that is usually ascribed to human persons. This position is founded on the premise that the blastocyst is not a human person at all; consequently it does not have rights and dignity. For example, Mary Warren (1994) and Judith Thomson (1994) argue that the human embryo is not a person from conception. Thomson (1994) in particular argues: "A newly fertilized ovum, a newly implanted clump of cells, is no more a person than an acorn is an oak tree" (p.283). Warren (1994) also argues that the blastocyst is "not the sort of entity to which it is proper to ascribe full moral rights" (p.302). You can read 
Francis (2016) for the full arguments on whether or not the blastocyst is a person. Meanwhile, Article I of the Universal Declaration of Human Rights states that "all human beings are born free and equal in dignity and rights." In other words, human beings are said to possess dignity by the fact of being humans. It follows that if the blastocyst is not human person with full moral status, then the blastocyst lack basis to be ascribed human dignity. At this juncture, it is important to point out that Kant's notion of human dignity would make sense if the personhood of the blastocyst has been firmly established. It is obvious that Kant did not intend to stretch his notion of human dignity to cover the blastocyst. Therefore, using Kantian logic to argue for the moral worth and dignity of the blastocyst seems to be out of place or fallacious.

Besides, it has been argued that the value and dignity of the human person is intrinsically given. Since for the opponents of hES cell research the blastocyst is a person; using the it in research amount to devaluation of the blastocyst and an undermining of its personal dignity and moral worth. Although the issue of the personhood of the blastocyst is discussed in full elsewhere (see Francis, 2016); it is important, however, to assert that human worth, valued or dignity is not intrinsic but pragmatic. My argument is based on the fact that human worth, value or dignity is not a biological entity of any individual human being. This means that human worth, value or dignity is external to man. In other words, no individual human being is born with inherent worth, valued and dignity.

Every individual human person acquired his worth and dignity from the society. This also goes to mean that outside the society man is worthless, valueless and without dignity. Individuals and things are not valuable unto themselves but unto the other (Aristotle, 1996). The value and worth of a being or thing is measured by its usefulness to the society. For example, a work of art is not valuable in itself but by its potential uses and benefits. Furthermore, a piece of article (for example, Achebe's Shoe) may be valuable not in-itself but for the fact that it has been used by a certain great individual. An individual may be dignified because he is from a certain great lineage, just like an individual may be de-dignified because of his family history. Human dignity is the off-shoot of human worth and value, and is not intrinsically given.

The idea of the intrinsic quality of human worth and dignity is based on Plato's concept of forms. According to Plato (1997), human beings are created with a priori essences (value, worth, dignity, purpose, etc) which manifest upon their birth. It is on the basis of this view that "essence precedes existence" that the beliefs on predestination, destiny and creationism are based. It is also upon that view by Plato that the argument of the intrinsicity of human dignity and worth is based. For instance, it could be argued that if Albert Einstein did not born, (or his blastocyst had been used for research) there would not have been the theory of relativity; which goes to mean that the capacity or value of Einstein as the propounder of the theory of relativity was intrinsically given. A Lockean answer would be that the mind of man at birth is a tabula rassa, a clean-empty slate (Locke, 1994).

My argument is that the value, worth or dignity of any individual (Albert Einstem for example) is not intrinsically given. This assertion is further strengthened by the fact of death. The fact of death implies that human being is a contingent and dispensable being. The contingency of the being of man implies that the reality and existence of the individual human being is not a necessity. This leads to this conclusion that: since man is a contingent being, as demonstrated by the fact of death, his worth of man with its attendant dignity is not intrinsically given.

However, Cicero cited in Barilan and Siegal (2005) argues that it is dignity that marks out humanity from the rest of nature; but that dignity is in the fact that man has a mind which aims at study and reflection. This means that not every time an individuals or a things that is said to possess value or worth elicits dignity $-\mathrm{a}$ work of art for example. But certainly, no individual human being elicit dignity (or is conferred dignity) if he fails to hold up promising worth. From Cicero, it can be deduced that not all human beings have or deserve dignity because not all human being have mind which "aims at study and reflection" - lunatics for example. It follows that if the blastocyst is a human being at all, then the blastocyst will not have or deserve any dignity since it does not have a mind which aims at study and reflection.

Austriaco (2008) as well as Teo and Calbreath (2006) argue that the blastocyst is a person and whose personal dignity is grounded on the assumption that human beings are made in the image of God. This view is based on the creation story that the "homo prima" was created by a certain god in its likeness and image. The view is inherently self-contradictory because the creation story did not state that god created Adam as a blastocyst but as a full grown individual. Secondly, the creator-god is said to be formless and gender-free (Tucker, 1992); now from what form, then did the "homo prima" copied its form, if god, the said creator, is formless? Hence, the argument that the blastocyst is a person with dignity and worth since it was created in god's image is false, fallacious or misleading.

Apart from that, the gradualists led by Robert Boomsma (2004) argue that there are degrees of value of a life depending on the stage of that life; consequently, there are degrees of respect or dignity that ought to be shown to that life at those stages - as embryo gradually develop into a fetus, then to a child and finally to the adult. In other words, there are degrees of worth and dignity in a person's life which are calibrated in accordance with the various stages in life. This view found local support in Africa's theory of human worth and dignity - of

DOI: 10.9790/0837-2109140712 $\quad$ www.iosrjournals.org $\quad 8 \mid$ Page


which the older an individual become in the community the greater his worth and dignity for which reason wisdom is calibrated to age (Momoh, 2000). This view also finds grounds in the Lockean notion of "tabula rassa"; which may be interpreted that a person worth is measured against the totality of his sense data.

However, as Hug (2006) argues to the contrary, "if our lives are worthy of respect simply because we are humans, it would be a mistake to think that at some younger age or earlier stage of development (e.g. when we began our lives as fertilized eggs) we were not worthy of respect." The problem of the gradualist view, with exception of the Locke's tabula rassa, is that it tends to view human worth, value and dignity as biological entities that increases with age, physiological growth and anatomical development. As I argued earlier, there is no gland in the human body that secrets value, worth and dignity into the biological system; rather the worth, value or dignity of any human person is pragmatically determined, not by the individual concern but by the community that he belongs or lives.

R.M. Green quoted in Teo and Calbreath (2006) argues that "there is really no single criterion to determine the moral status of the embryo, and instead, we (as individuals and as a society) choose the point at which the embryo becomes worthy of moral respect through a process of weighing multiple considerations." In other words, Green is saying that moral worth or dignity is not a biological entity but the convention of the community. Yet, Segura and Delgado aver that our moral judgment concerning the blastocyst may be essentially based on emotion and our religious biases. Since our moral judgment about the moral worth of the blastocyst may be founded on our emotions, we cannot trust or guarantee that the consideration of the blastocyst as a human person with worth and dignity is not arbitrary and emotional.

This, however, reverts us to the nagging question of whether or not the blastocyst is a human person at all? An honest and effective answer to the question shall equally determine whether the blastocyst have and deserve any moral worth and human dignity. The question of the personhood of the blastocyst is treated in a different paper (see Francis, 2016).

\section{THE QUESTION OF RIGHT TO LIFE}

One of the prevalent moral questions in hES cell research is that the blastocyst has a moral right to life which the stem cell research supposedly violates. The argument that the blastocyst has a moral right to life is founded on a more fundamental notion that the blastocyst is a human person with full moral status as you and I. Those who oppose hES cell research argue that the research involves deliberate killing of the blastocyst - which according to them, has a moral right to life which must be protected (Rickard, 2002). The argument that the blastocyst has moral right to life is further based on the earlier discussed notion that the blastocyst has intrinsic value and worth which hES cell research voids.

The belief that the blastocyst is a human person with right to life has led some ethicists to describe the research as condemnable act of wanton destruction of the blastocyst: Immoral, unjust and an act of aggression, even murder against the unborn and radically an unethical act that is evil (Iroegbu, 2005a). Furthermore, Hug (2006) notes that the opponents of hES cell research argue that "since a human embryo is believed to have a status of a human individual from the moment of the fertilization of the egg, it has the right to its own life, and every intervention not in favour of the embryo is a violation of that right."

It is worthy of note that various religious systems have opinions about stage in development the embryo is said to possess a moral right to life. All world regions except Christianity, seems to have accepted the view that the blastocyst does not "yet" have a moral right to life. This disagreements among Christian theologians have been pointed out by Boomsma (2004) that, a consensus has not been reach within the Christian community on whether or not the blastocyst have any right to life.

On the other hand, those who support hES cell research argue that the blastocyst is not a human person with a moral right to life. For them, since the blastocyst is not a human person, ascribing a right to life to it is no more a right to life given to any other tissue in the body (Hug, 2006). There is also the intermediate position that ascribes moral right to life to the embryo at some point of vitality (Brody, 1994).

At this juncture, it is important for us to discuss what it means to have a right to life. The argument that an individual possesses an inalienable right to life is founded on the natural rights doctrine, which views right to life, in particular, as prior to existence or human reality. It from the galaxy of natural rights that human beings are said to have derived moral right to life (Ndubuisi \& Nathaniel, 2002). And because the opponents of hES cell research believe that the blastocyst is a human person with full moral status, it follows that the blastocyst has an inalienable right to life. The "rights precede man" doctrine has been rejected by the legal positivists. For example, Thomas Hobbes argued that rights are not prior to man because in the "state of nature" there were no laws and rights (Uduigwomen, 2005). This was to be followed by the existentialist doctrine that man first of all exists before it creates values, rights and laws unto itself (Sartre, 1994). In other words, 'existence precedes values', 'man precedes rights'. Hence, Jesus the Nazarene said laws were made for man and not man for the laws. Kant, on the other hand, avers that it is man that makes laws and imposes it on nature (Kant, 1934). In other words, rights are not prior to man. If rights are creations of man and not prior to man, does it still subsist 
that right to life of individual humans is inalienable, absolute and part of human nature? Iroegbu (2005b) argues that:

Life is a right to all who live, it is an imperative. One may not have the right to exist, i.e., to have come to be in the first instance. But once one has come to exist, once one has been conceived and delivered, that one should not be denied the right to continue to exist without serious justification (p.447-8).

In other words, Iroegbu is saying that right to life is not inalienable, and that individuals must first exist in order to enjoy right to life at all. Rickard (2002) also maintains that "even if embryos were shown to have moral status [with right to life] it can be argued, that still might not necessarily mean that embryos should never be intentionally destroyed" (p.8). Hug (2005) also argues that, "even if destruction of human embryos as a result of conducting research is viewed as 'killing', it can be argued that the moral obligation not to kill, although very strong, is not one that can never be overridden." For example, assassinating Hitler and saving six million Jews.

Moreover, some scholars had argued that the embryo acquires moral right to life at some stage in its development, particularly at vitality (Brody, 1994). It is on this ground that the Roe vs Wade ruling was based. This is obviously the grand view of the gradualists - that considers the embryo as acquiring personhood vis-àvis moral right to life at some point of vitality, mid-way between conception and birth (Boomsma, 2004). These positions and views are founded on a more fundamental philosophy that right to life is derived from human nature.

The inalienable rights [including right to life] that are called natural are found as principles ingrained in human nature, which can be understood from ontological view point. This is suggestive of the fact that the principles of natural rights are derived from a source that is more intrinsic and fundamental... Reason impels man to use his primordial instinct of goodness to probe his nature in order to discover natural right... natural rights are not man-made since they are principles embedded in human nature (Ndubuisi \& Nathaniel, 2002, p.172).

The view above makes right to life of an individual appear prior to man; and it is rooted in Jacques Maritain's argument that natural laws are written into the human nature by God. And it is further founded on the Platonist doctrine of forms, of 'rights precede essence'. If moral right to life is acquired at some point between fertilization and birth, it would mean that the right to life of an individual is a biological entity that develops alongside tissues in the human body. But moral rights of an individual are not biological entities.

The so-called natural rights are enforceable rights granted members of the community by the community (Uduigwomen, 2005). Since right to life is not a biological entity that is acquire at some point between fertilization and birth, it follows that right to life is conferred only on visible members of the community. As the blastocyst is not legal member of the human community, it follows that the blastocyst does not have a moral right to life. Suffice it to state that because of the non-inalienable and viodability of right to life, and for the fact that right to life is not ingrained in human nature; right to life is an extrinsic quality instead of intrinsic.

Apart from that, Rickard (2002) states that it is a generally held opinion that the reasons for promoting life is that "loss of life causes various sorts of harm - to the killer, the society in general, and most importantly the deceased" (p.10). He notes that those who oppose hES cell research had relied on that view to argue "that loss of embryonic life is a harm, inflicted on the embryo" by using it in research. Citing Joel Feinbery, he argues that the concept of harm is in terms of the thwarting, setting back or defeating of an interest. Yet, having interest entails having beliefs, desires, expectations, aims and purposes; these, he holds, are what are thwarted when harm is inflicted on an individual. Although the embryo has potential interests, he holds, which are nonetheless inconsequential, destroying the blastocyst during research does not cause harm to it since its interests are merely potential and not actual.

Hug (2006) states that the advocates of hES cell research argue, rightly, that the nervous system of the blastocyst is not yet developed enough for it to have any interest which could be thwarted. However, it is important to point out that even if the blastocyst were to develop complete nervous system, it would still lack the capacity to develop its own interest. This is so because interests, be they beliefs, desires, expectations, aims and purposes - are products of thought, and they reside in thought (Ogbinaka, 2010). Therefore, it could be said that they are always perpetually in a state of potency. The embryo, even with complete nervous system, lacks the capacity to develop any interest at all that could be thwarted. Thwart-able interests are product of the external world which the embryo, even at ninth month, has no access.

According to Locke, the mind of any human being at birth is a tabula rassa and so whatever is known or haboured as interest is not prior to experience. Kant also said that whatever is haboured in our mind as ideas or interests are gathered from experience but subject to the categories of the mind (Kant, 1934). Thoughts, be it ideas or interest, are not prior to experience. Edmund Husserl avers that thoughts or interests are always directed at something (Unah \& Osegenwune, 2010). Now, what exactly is the embryo thinking about and what does it direct its interest or thought. It leads us once again to the argument I advanced earlier that the embryo may

DOI: 10.9790/0837-2109140712 $\quad$ www.iosrjournals.org $\quad 10 \mid$ Page


develop a complete brain and nervous system yet it remains largely a bundle of unconscious tissues because consciousness is impossible outside the external world of experience.

Another argument usually marshalled against hES cell research is that the blastocyst is a potential person with potential right to life, and so the inevitable destruction of blastocyst during research amount to depriving the blastocyst the opportunity to actualize that right, or to assume that right in actuality (Hug, 2006). Firstly, the argument is lopsided because it views right to life as being part and parcel of the human biological system. Secondly, if the blastocyst is a potential person at all, then whatever right to life it has is merely a potential right, and not the actual right. Therefore, the inevitable destruction of the blastocyst during research has not violated this right, since the right is only a probability and not the actual right to life.

Having stated thus, I maintain that all moral rights come with correspondent moral responsibilities. If the blastocyst has a moral status with attendant moral right to life, then what moral responsibility does the blastocyst owe the community? Every individual with full moral status and its attendant right to life has a moral responsibility of contributing to the welfare of the community; if the blastocyst has moral status, then what are its moral responsibilities to the community? I assert that the blastocyst is neither a human person nor a potential human person.

Now, what does it mean to have right to life from the legal perspective? Chapter IV of the 1999 Constitution of Nigeria (Amended) declares that "every person has a right to life." Rickard (2002) states that right to life means "the human right not be killed, and the moral obligation not to kill persons" - unjustly (p.9). This means that the criterion for right to life is the possibility to be killed and capability to kill. This criterion shows that right to life is necessarily in dual folds - protection and prevention, privilege and obligation, right and duty. The absence of one aspect automatically renders the other impossible. In other words, you cannot be said to possess right to life if you are only protected from being killed without the correspondent obligation not to kill persons and vice versa. Indeed, it is impossible to possess moral rights without correspondent moral responsibilities. This, in my view, is what Rickard meant by right to life.

This now takes us to the heart of this research of whether the blastocyst, in practical terms, can execute the moral obligation that goes with the privilege of not being killed arbitrarily. Obviously, the blastocyst cannot fulfil that moral obligation because the realization of that obligation can only be possible in the community of people, and not outside it. It therefore means that the blastocyst does not possess right to life at all. It is impossible for a moral right to exist in practical terms without its correspondent moral obligation. Both moral right and moral responsibility co-exist, and none can exist without the other. It is the existence of moral obligation that validates moral right. In other words, no being or entity can assume moral status if it lacks the capacity to assume moral responsibilities as well. A critical investigation has shown that the blastocyst lacks the capacity to assume moral responsibilities.

Further, if moral right to life involve as well, a right not to be killed; Olopade (2008) states that for a being to be capable of being killed in Nigerian and English common law, two conditions must be met - namely: (a) the being must be completely extruded from the mother's womb (b) the being must have an existence independent from that of the mother. Before a person dies, he must be born. This means that, in common law, the blastocyst does not have life that could be deprived in the first place. Therefore, in the eyes of the common law, the blastocyst does not have right to a life because it does not possess in the first place. Olopade (2008) then argues that "it is wrong and unjust therefore to regard the termination of an abortus as tantamount to murder" (p.27). That which has not been born cannot be said to have died. That is to say, that which has not been born or given birth to, which has no life in the first place, which has not been regard as a person in law, cannot be said to have a right to life capable of being violated by hES cell research.

If logical argumentations have shown that the blastocyst is not a person capable of being killed, then what does it mean to be a person - is it birth alone that can confer personhood on beings or are they other criteria that determine personhood of a being? Dealing with these questions is important to survival of hES cell research. I have articulated deep, ethical and logical answers to these personhood questions in another paper (see Francis, 2016).

\section{CONCLUSION}

In conclusion, this study clearly indicates that the arguments of the anti hES cell research and gradualists are based on weak conceptual frameworks, and thus lack logical depth to warrant deterring research involving use of embryos. One point clearly pointed out in this study is that the arguments of the gradualist presents right to life and human dignity as biological entities that develop gradually as somatic tissues in the body. The anti hES cell advocates misinterpreted Kant deonotologic arguments, and also failed to realize that the concept of "image of God" did not apply to the embryo but only grown humans. Finally, it is important to remind ourselves that there is no unanimous position among ethicists regarding the ethics of hES cell research, except the general agreement on the utilitarian aims of the research. Boomsma (2004) rightly notes that "work with hES cell has not progressed as far as in animals." This means simply that much work remains in the field. 


\section{REFERENCES}

[1] Aristotle (1996). The Nicomachean Ethics. Trans. Harris Rackham. Hertfordshire: Wordsworth editions Limited.

[2] Austriaco, N. (2008). Understanding Stem Cell Research Controversy and Promise. New Haven: Catholic Information Service.

[3] Barilan, M. \& Siegal, G. (2005). The Stem Cell Debate: A Jewish Perspective on Human Dignity, Human Creativity and Inter-religious Dialogues. In Wolfang Bender, Christine Hauskeller \& Alexandria Manzei (Eds.), Crossing Borders. Munster: agenda Verlag.

[4] Boomsma, R. A. (2004). Embryonic Stem Cells and a Reformed Christian Worldview. The Perspectives on Science and Christian Faith, 56 (1): 38-48.

[5] Brody, B. (1994). The Morality of Abortion. In Tom L. Beauchamp \& LeRoy Walters (Eds.). Contemporary Issues in Bioethics $4^{\text {th }}$ ed. California: Wadsworth Publishing Co.

[6] Federal Republic of Nigeria. 1999 Constitution of the Federal Republic of Nigeria (Amended). Abuja: Government Printer.

[7] Francis, D.I.A. (2016). A Critical Examination of the Question of personhood in Stem Cell Research. Journal of Humanities and Social Sciences, 21(8.9): 6-13.

[8] Hug, K. (2005). Sources of Human Embryo for Stem Cell Research: Ethical Problems and their Possible Solutions, Department of Social Medicine, Kaunas University of Medicine, Lithuania, 2005.

[9] Hug, K. (2006). Therapeutic Perspectives of Human Embryonic Stem cell Research Versus the Moral Status of a Human Embryo: Does One Have to be compromised for the Other? Medicina (Kaunas), 42(2): 107-114.

[10] Iroegbu, P. (2005a). Stem Cells: Technology and Ethics. In Pantaleon Iroegbu and Anthony Echekwube (Eds.), Ethics: General, Special \& Professional. Ibadan: Heimann Educational Books Plc.

[11] Iroegbu, P. (2005b). Right to Life and the Means to Life: Human Dignity. In Pantaleon Iroegbu and Anthony Echekwube (Eds.), Ethics: General, Special and Professional. Ibadan: Heinemann Educational Books Plc.

[12] Kant, I. (1943). Critique of Pure Reason. Trans. J. M. D. Meiklejohn. London: J. M. Dent \& Sons Ltd.

[13] Kant, I. (1949). Fundamental Principle of the Metaphysic of Morals. Trans. Thomas K. Abbott. Indianapolis: The Bobbs-Merrill Company, Inc.

[14] Locke, J. (1994). An Essay Concerning Human Understanding. In Donald C. Abel (Ed.), Fifty Reading in Philosophy. New York: McGraw-Hill Inc.

[15] Momoh, C. S. (2000). The Function of Eldership in African Marriages. In C.S. Momoh (Ed.), The Substance of African Philosophy 2nd Ed. Auchi: African Philosophy Projects Publications.

[16] Ndubuisi, F. N. \& Nathaniel, O. C. (2002). Issues in Jurisprudence and Principles of Human Rights. Lagos: Foresight Press Ltd.

[17] Ogbinaka, O. M. (2010, Jul.). Lecture Note on F.H. Bradley. Department of Philosophy, University of Lagos, Nigeria.

[18] Olopade, O. (2008). Law and Medical Practice in Nigeria. Ibadan: College Press \& Publishers Ltd.

[19] Plato (1997). Republic. Trans. John Llewelyn Davies \& David James Vaughan. Hertfordshire: Wordsworth editions Limited.

[20] Rickard, M. (2002). Key Ethical Issues in Embryonic Stem Cell Research. Department of the Parliamentary Library Australia.

[21] Sartre, J. P. (1994). Existentialism is a Humanism. In Donald C. Abel (Ed.), Fifty Reading in Philosophy. New York: McGraw-Hill Inc.

[22] Segura, J. V. \& Delgado, M. (2016, Jun. 24). Values in Controversies: Stem Cell Research. Departmento de Filosofia, Universidad Autonoma de Barcelona, Spain.

[23] Teo, A. \& Calbreath, D. (2006). Embryonic Stem Cells and a Reformed Christian Worldview: A Response to Robert Boomsma. The Perspectives on Science and Christian Faith, 58(3): 179-188.

[24] Thomson, J. J. (1994). A Defense of Abortion. In Tom L. Beauchamp \& LeRoy Walters (Eds.), Contemporary Issues in Bioethics 4th ed. California: Wadsworth Publishing Co.

[25] Tucker, D. (1992). In the Image of God: Freedom. The Gospel Advocate, 134 (8).

[26] Uduigwomen, A. F. (2005). Studies in Philosophical Jurisprudence 2nd ed. Calabar: Jochrisan Publishers.

[27] Unah, J. \& Osegenwune, C. (2010). Phenomenology and Existentialism. Lagos: Fadec Publishers.

[28] Warren, M. A. (1994). On the Moral and Legal Status of Abortion. In Tom L. Beauchamp \& LeRoy Walters (Eds.). Contemporary Issues in Bioethics $4^{\text {th }}$ ed. California: Wadsworth Publishing Co. 